\title{
A Soluble C1b Protein and Its Regulation of Soluble Type 7 Adenylyl Cyclase ${ }^{\dagger}$
}

\author{
Jeff A. Beeler, \\ Ben May Cancer Research Institute and Committee on Neurobiology, University of Chicago, Chicago, Illinois 60637, and \\ Department of Chemistry, University of Pittsburgh, Pittsburgh, Pennsylvania 15260
}

Received May 5, 2004; Revised Manuscript Received August 6, 2004

\begin{abstract}
Adenylyl cyclase (AC) is a prototypical cell-signaling molecule expressed in virtually all organisms from bacteria to man. While $\mathrm{C} 1 \mathrm{~b}$, a poorly conserved region within mammalian $\mathrm{AC}$, has been implicated in numerous isoform-specific regulatory properties, no one has purified the $\mathrm{C} 1 \mathrm{~b}$ region as a functional protein to homogeneity in order to study its role in enzyme function. We hypothesize that $\mathrm{C} 1 \mathrm{~b}$ is an internal regulatory subunit. To pursue this hypothesis, we constructed several soluble $\mathrm{C} 1 \mathrm{~b}$ proteins from type VII AC, arriving at one, 7C1b-S, which can be expressed and purified from Escherichia coli. 7C1b-S is relatively stable, as demonstrated by limited proteolytic analysis, circular dichroism, and UV Raman spectroscopy. Using size-exclusion chromatography and co-immunoprecipitation we demonstrate that $7 \mathrm{C} 1 \mathrm{~b}-\mathrm{S}$ interacts with a cardinal activator of $\mathrm{AC}(\mathrm{Gs} \alpha)$ and with the conserved first catalytic domain (C1a) of type VII AC. We show that 7C1b-S inhibits Gso-stimulated and Gs $\alpha$-forskolin stimulated activity in our soluble ACVII model system. On the basis of these results, we suggest that $7 \mathrm{C} 1 \mathrm{~b}-\mathrm{S}$ meets basic criteria to serve as a model protein for the $\mathrm{C} 1 \mathrm{~b}$ region and may be used as a prototype to develop other isoform $\mathrm{Clb}$ soluble model proteins to further investigate the role of this domain in isoform-specific regulation of adenylyl cyclase.
\end{abstract}

Adenylyl cyclase (AC) ${ }^{1}$ represents a large family of enzymes expressed in virtually every organism from bacteria to man. AC plays a role in diverse physiological functions from regulation of sugar metabolism to formation of memory and responds to myriad activators and modulators, including a broad family of G-proteins (Gs $\alpha$, Gi $\alpha$, Go, Gz, G $\beta \gamma$ ), calcium ion, calmodulin, calcineurin, PKC, PKA, CaM kinase IV, adenosine analogues, divalent cations, RGS2, and peptidyl prolyl isomerases (for reviews, see refs $1-7$ ). In mammals, there are nine known isoforms of membrane bound $\mathrm{AC}(5,6)$, all of which share the same topology: a short cytoplasmic $\mathrm{N}$-terminus domain $(\mathrm{N})$, followed by a transmembrane-spanning domain (M1), followed by a cytoplasmic domain (C1), another transmembrane domain (M2), and finally a second cytoplasmic domain (C2) $(3,8$, 9). Within the two cytoplasmic loops are two regions ( $\mathrm{Cla}$ and $\mathrm{C} 2 \mathrm{a}$ ) that are homologous with each other and highly conserved across isoforms and together constitute the

${ }^{\dagger}$ Funding for this research was provided by National Institutes of Health Grant M53459 to W.J.T. and GM8RO1EB002053021 to S.A. The peptide sequencing/amino acid composition carried out by Kelly M. Levasseur at the Protein Analysis Shared Facility of the Cancer Center at the University of Alabama Birmingham (UAB) was supported by the NIH (CA 13148).

* To whom correspondence should be addressed. Telephone: (773) 702-4331. Fax: (773) 702-3701. E-mail: wtang@uchicago.edu.

$\$$ Ben May Cancer Research Institute, University of Chicago.

$\S$ Committee on Neurobiology, University of Chicago.

"Department of Chemistry, University of Pittsburgh.

${ }^{1}$ Abbreviations: AC, adenylyl cyclase; RGS2, regulator of G protein signaling 2; Fsk, forskolin; DTT, dithiothreitol; CaM, calmodulin; TFA, triflouroacetic acid; CD, circular dichroism; UVRS, UV resonance Raman spectroscopy; EDTA, $N$-(2-hydroxyethyl)ethylenediamine-triacetic acid; SDS-PAGE, sodium dodecyl sulfate-polyacrylamide gel electrophoresis; Ni-NTA, nickel-nitrilotriacetic acid. catalytic core of the enzyme. Catalysis is enabled by the juxtaposition and proper alignment of these two domains within the native enzyme (10).

The complexity of AC signaling-which is controlled primarily at the level of synthesis (11)-arises from combinatorial expression of different isoforms in different tissues. That is, each isoform has both shared and unique regulatory properties and each tissue expresses at least two isoforms $(4,6,12)$. Thus, the properties of AC signaling within a given tissue arise as a result of the integration of the properties of the specific isoforms expressed in that particular cell type (7). Isoform specific regulation, then, is an important aspect of AC signaling. Several lines of evidence have pointed to a small, less conserved (and less studied) region of $\mathrm{AC}, \mathrm{C} 1 \mathrm{~b}$, as potentially important in conferring isoform specific regulatory properties. In $\mathrm{ACI}$, the calmodulin binding site has been localized to residues within the $\mathrm{Clb}$ region (ACI, aa 495-522) (13-15). $\mathrm{Ca}^{2+}$ regulation of ACV may involve the $\mathrm{C} 1 \mathrm{~b}$ region $(\mathrm{ACV}$, aa $571-683)(16) .6 \mathrm{Clb}$ and $5 \mathrm{C} 1 \mathrm{~b}$ alter the Gs $\alpha$ response profile of these isoforms, possibly due to a second Gs $\alpha$ binding site $(17,18)$. In ACVI, C1b is the site of feedback inhibition from PKA (18). C1b may also play a critical role in isoform sensitivity to $\mathrm{G} \beta \gamma$. $\mathrm{G} \beta \gamma$ inhibits ACI activity but potentiates ACII activation (19). The $2 \mathrm{C} 1 \mathrm{~b}$ region has been shown to be critical for ACII sensitivity to $\mathrm{G} \beta \gamma$ (20). In ACI, although the $1 \mathrm{C} 1 \mathrm{a}$ region alone is sufficient to confer $\mathrm{G} \beta \gamma$ responsiveness, $1 \mathrm{C} 1 \mathrm{~b}$ together with $\mathrm{C} 2$ can form a second site, conferring additional $\mathrm{G} \beta \gamma$ sensitivity (21).

To date, no systematic investigation has been done to determine whether $\mathrm{C} 1 \mathrm{~b}$ can serve as a functional, modular domain nor what might be the molecular mechanism underlying such diverse regulatory actions of $\mathrm{Clb}$ across 
different isoforms. To this end, we set out to construct a functional, soluble $\mathrm{C} 1 \mathrm{~b}$ protein derived from ACVII as a prototype for developing isoform-specific $\mathrm{Clb}$ models. Previously we reported the construction, purification, and characterization of a $7 \mathrm{C} 1 \mathrm{~b}$ soluble protein; however, such a $7 \mathrm{C} 1 \mathrm{~b}$ protein was difficult to purify and labile (22). We report here the development and biophysical and biochemical characterization of a relatively stable $7 \mathrm{C} 1 \mathrm{~b}$ soluble protein, 7C1b-S.

\section{MATERIALS AND METHODS}

Materials. Forskolin (Fsk) is from Calbiochem (La Jolla, CA). Restriction enzymes and Vent DNA polymerase are from New England Biolabs (Beverly, MA). $\alpha-{ }^{32} \mathrm{P}-\mathrm{ATP}$ is from NEN Life Science Products (Boston, MA). Ni-NTA resin is from Qiagen, and Q-sepharose and Superdex 200 resin are from Amersham Biosciences (Piscataway, NJ). SuperSignal West Pico Chemiluminescent Substrate reagent is from Pierce Laboratories (Rockford, IL). Chymotrypsin is from Roche Diagnostics (Indianapolis, IN), and Proteinase $\mathrm{K}$, endoproteinase $\mathrm{GluC}$, and $\mathrm{ArgC}$ are from Sigma (St. Louis, MO). The anti-EE and 12CA5 hybridomas were kindly provided by G. Walter at University of California at San Diego and R. Lerner at Scripps Institute, respectively.

Plasmids. The coding sequence for 7C1b-S (aa 506-584 in ACVII) was amplified by 18 cycles of polymerase chain reaction (five cycles at $45^{\circ} \mathrm{C}$ annealing, 13 cycles at $55^{\circ} \mathrm{C}$ annealing) using human ACVII as the template, vent DNA polymerase, and the following primers:

5'-GGCGT/GGCGA/ATTCG/TGAGC/AGTGG/TGAGA/ CCCAC/GTCCC/C-3' and 5'-ACTCA/CTTGC/GGCCG/ CTATT/ACTCG/CGCTC/AAAGC/CCTTC/T-3'. The resulting DNA products were digested with EcoRI and NotI restrictions enzymes and ligated into pProEx-H6EE that was digested with the same enzymes. The resulting pProExH6EE-7C1b-S plasmid was verified by DNA sequencing.

Expression and Purification of $7 \mathrm{C} 1 \mathrm{~b}-\mathrm{S}$. To express $7 \mathrm{C} 1 \mathrm{~b}-$ $\mathrm{S}$, pProEx-H6EE-7C1b-S was transformed into BL21(DE3) Escherichia coli. Cultures were grown in $\mathrm{T} 7$ medium containing $50 \mu \mathrm{g} / \mathrm{mL}$ ampicillin at $30^{\circ} \mathrm{C}$. When cell density reached $\mathrm{OD}_{600}=0.45$, IPTG was added to $100 \mu \mathrm{M}$, and cells were cultured for an additional $20 \mathrm{~h}$. Cultures were harvested and cells lysed and purified using Ni-NTA and Q-sepharose columns (23). Fractions from Q-sepharose elution containing $7 \mathrm{C} 1 \mathrm{~b}-\mathrm{S}$ were pooled and dialyzed into a buffer including $50 \mathrm{mM} \mathrm{NaCl}$. The retentate was concentrated to approximately $400 \mu \mathrm{M}$. Concentration was determined using $\mathrm{OD}_{280}$ with $1 \mathrm{mg} / \mathrm{mL}=0.36 \mathrm{AU}(24)$. 7C1b-S used in circular dichroism, UV Raman, and proteolytic experiments was further purified through size-exclusion chromatography using a Superdex 200 column (Amersham Biosciences, Piscataway, NJ).

Limited Proteolysis. All proteolysis experiments were conducted in $25 \mu \mathrm{L}$ reaction volumes in a buffer of $50 \mathrm{mM}$ Tris pH 7.5 and $25 \mathrm{mM} \mathrm{NaCl}$, with $200 \mu \mathrm{M}$ DTT (residual from addition of $7 \mathrm{C} 1 \mathrm{~b}-\mathrm{S}$ to reaction) at $37{ }^{\circ} \mathrm{C}$. $7 \mathrm{C} 1 \mathrm{~b}-\mathrm{S}$ concentration was $0.2 \mathrm{mg} / \mathrm{mL}(\sim 20 \mu \mathrm{M})$, except for the proteinase $\mathrm{K}$ reaction, done with $0.3 \mathrm{mg} / \mathrm{mL}(\sim 30 \mu \mathrm{M})$. All reactions were stopped by heating digests to $100{ }^{\circ} \mathrm{C}$ for 5 min, and $1 \mathrm{mM}$ DTT added to prevent unwanted disulfide bond formation. Incubation times: proteinase K, 5, 10, and
$30 \mathrm{~min}$; chymotrypsin, $30 \mathrm{~min}, 2$ and 8 h; endoproteinases GluC and ArgC, 2, 8, and 20 h. Digests were performed with either a 1:5 (chymotrypsin, endoproteinases GluC and ArgC) or 1:10 (proteinase K) serial dilution of protease. $1 \times$ was used for each of the following enzymes: proteinase $\mathrm{K}$, $4 \mathrm{ng} / \mathrm{mL}$; chymotrypsin and endoproteinases $\mathrm{GluC}$ and $\mathrm{ArgC}$, $4 \mu \mathrm{g} / \mathrm{mL}(1: 50 \mathrm{w} / \mathrm{w}$ 7C1b-S:protease). During analysis of fragments identified by Maldi-TOF mass spectroscopy, a region/site was categorized as protected, semiprotected, or vulnerable according to the following semiquantitative criteria: protected, no fragments observed beginning or ending at this site or within this region; semiprotected, few fragments (two or three) observed beginning or ending at this site or within this region; vulnerable, many fragments (more than three) observed beginning or ending at this site or within this region.

Maldi-TOF Mass Spectroscopy. Experiments were conducted on a Voyager instrument (PerSeptive Biosystems, Framingham, MA). One microliter of sample was applied to a titanium sample plate and $1 \mu \mathrm{L}$ of matrix compound was added ( $\alpha$-cyano-4-hydroxycinnamic acid in 50\% acetonitrile) at a concentration of $10 \mathrm{mg} / \mathrm{mL}$ with $0.1 \%$ triflouroacetic acid (TFA) and allowed to air-dry. The program FindPept (http://us.expasy.org/tools/findpept.html) was used to identify fragments from their experimental mass. Analysis was conducted using average mass (vs monoisotopic) and cysteines in reduced form and including the potential modifications of oxidized methionines and $\mathrm{N}$-formylation. All analyses were conducted with raw mass-charge data in addition to data with $23 \mathrm{Da}$ added to each fragment to account for a possible sodium ion bound to fragments during ionization.

High-Performance Liquid Chromatography and N-Terminal Sequencing. TFA was added to the digest reaction (see above) to $0.1 \%$ and injected into a reverse phase analytical column (Varian Dynamax C-18, Vydak) using a Beckman System Gold HPLC instrument with a diode array detector. Peptide fragments were separated using a water:acetonitrile gradient $(0.1 \%$ TFA). Peaks were detected at 220 and 280 $\mathrm{nm}$. Collected peaks were concentrated by approximately $50 \%$ with vacuum centrifugation to remove TFA and acetonitrile. Peptide sequencing/amino acid composition was carried out by Kelly M. Levasseur at the Protein Analysis Shared Facility of the Cancer Center at the University of Alabama Birmingham (UAB). Approximately 100 pmol of peptide fragment in water was applied to a peptide support disk (Beckman) and sequenced using a Beckman Model PI 2090E instrument.

Circular Dichroism. CD experiments were conducted on an Aviv 202 instrument. CD spectra were measured from 190 to $260 \lambda(\mathrm{nm})$ typically with $2 \mathrm{~s}$ averaging time per wavelength, generally utilizing three scans per measurement. A $0.1 \mathrm{~cm}$ quartz cuvette (Starna Cells, Atascadero, CA) was used with $400 \mu \mathrm{L}$ of sample. One of two buffers was used (as noted in Results): $5 \mathrm{mM}$ phosphate buffer, $\mathrm{pH} 7.2$ and $100 \mathrm{mM} \mathrm{KCl}$ (with a residual $42 \mu \mathrm{M}$ DTT from dilution of 7C1b-S stock) or $10 \mathrm{mM}$ phosphate buffer, $\mathrm{pH} 7.2,50 \mathrm{mM}$ $\mathrm{NaCl}$, and $1 \mathrm{mM}$ DTT. Except for concentration-dependent studies, all measurements were conducted with $30 \mu \mathrm{M}$ 7C1b-S. Secondary structure analysis utilized analysis programs available in CDPro (25). Raw data are converted to mean per residue ellipticity and submitted to one of three 
analysis programs available within the suite (CONTIN/LL, SELCON3, or CDSSTR). A 43-protein reference set was selected for analysis. Generally, results from all three programs were in agreement. Presented here are the results from the CONTIN/LL analysis only, as that analysis showed the lowest root-mean-square deviation of the three.

UV-Resonance Raman Measurements. The UV Raman spectrometer has been described in detail elsewhere (26). Briefly, the third harmonic of a Coherent Infinity Yag Laser operating at $100 \mathrm{~Hz}$ with a $3 \mathrm{~ns}$ pulse width was Raman shifted by five anti-Stokes harmonics in 40 psi hydrogen gas to $204 \mathrm{~nm}$. The $0.1 \mathrm{~mL}$ sample solutions were pumped back and forth within a $1 \mathrm{~mm}$ diameter Suprasil quartz capillary by using a microsampling system, which uses a tiny air pump to reciprocate the solution (27).

The Raman scattering was collected at an angle close to backscattering and was dispersed with a double partially subtractive monochromator. The Raman scattered light was detected by using a Roper Scientific Model 7375-0001. The spectral accumulation times were $5 \mathrm{~min}$. The spectral resolution was $10 \mathrm{~cm}^{-1}$. The spectra were modeled as linear combinations of the individual secondary structure basis spectra as obtained by Chi et al. (28).

The UV Raman spectra were modeled using a linear model-pure secondary structure Raman spectra (PSSRS) in which each of the amide groups scatter independently and the spectra contributed derive from the previously determined basis spectra of the $\alpha$-helix, $\beta$-sheet, and disordered folded protein conformation. Prior to PSSRS modeling, we subtracted the spectrum of buffer as previously described (28). In addition we excluded the region containing the aromatic amino acid ring vibrations $\left(\sim 1610 \mathrm{~cm}^{-1}\right)$ and the $\sim 1450$ $\mathrm{cm}^{-1}$ region.

Size-Exclusion Chromatography. For all size exclusion chromatography experiments, we utilized a Superdex 200 column (Amersham Biosciences, Piscataway, NJ), loading either 400 or $500 \mu \mathrm{L}$ of sample with a flow rate of $0.3 \mathrm{~mL} /$ min, collecting $1 \mathrm{~min}$ fractions. Elution buffer: $50 \mathrm{mM}$ Hepes pH 7.2, 50 or $100 \mathrm{mM} \mathrm{NaCl}, 1 \mathrm{mM}$ EDTA, and 1 $\mathrm{mM}$ DTT. Fractions were examined by loading $10 \mu \mathrm{L}$ of each on an SDS-PAGE gel and then analyzing by Western blot.

Co-Immunoprecipitation. $7 \mathrm{C} 1 \mathrm{a}(0.7 \mu \mathrm{M})$ was incubated for $1 \mathrm{~h}$ in the presence or absence of $7 \mathrm{C} 1 \mathrm{~b}-\mathrm{S}(6 \mu \mathrm{M})$ in a co-immunoprecipitation buffer [50 mM Tris, $\mathrm{pH} 7.4,5 \mathrm{mM}$ EDTA, $0.5 \% \mathrm{NP}-40,200 \mathrm{mM} \mathrm{NaCl}$, and $2 \mathrm{mg} / \mathrm{mL}$ bovine serum albumin (BSA)] at $4{ }^{\circ} \mathrm{C}$. Anti-EE antibody was then added and incubated overnight to immunoprecipitate $7 \mathrm{Clb}-\mathrm{S}$ (targeting the EE epitope tag at the N-terminus of the protein). Then $15 \mu \mathrm{L}$ of a $50 \%$ slurry of protein $\mathrm{G}$ sepharose (Sigma-Aldrich, St. Louis, MO) was added and the mixture incubated for an additional hour (reaction volume, $200 \mu \mathrm{L}$ ). The reactions were then washed three times with the same buffer but with $1 \mathrm{M} \mathrm{NaCl}$ and either $0.75 \%$ or $1 \% \mathrm{NP}-40$ (as noted in Results). The resulting preparations were then loaded onto a SDS-PAGE gel and co-immunoprecipitation of 7C1a was tested with Western blot analysis using 12CA5 antibody (targets the HA epitope at the N-terminus of 7C1a).

Adenylyl Cyclase Assays. Adenylyl cyclase assays were performed with $0.1 \mathrm{mg} / \mathrm{mL} \mathrm{BSA,} 10 \mathrm{mM} \mathrm{MgCl}_{2}$, and 0.5 mM ATP at $30^{\circ} \mathrm{C}$ as described elsewhere (29). Recombinant Gs $\alpha$ was activated by $50 \mu \mathrm{M} \mathrm{AlCl}_{3}$ and $10 \mathrm{mM} \mathrm{NaF}$. The assay time varies by experiment. 7C1a, 7C2, and Gs $\alpha$ were prepared as described previously $(23,30,31)$ and used at concentrations indicated for each experiment.

\section{RESULTS}

Expression and Purification of $7 C 1 b-S$. We recently constructed a soluble protein derived from the $\mathrm{C} 1 \mathrm{~b}$ region of type 7 adenylyl cyclase (aa 483-596 in human ACVII) and found it inhibited adenylyl cyclase activity of soluble $7 \mathrm{C} 1 \mathrm{a} / 7 \mathrm{C} 2$ proteins. However, this $\mathrm{C} 1 \mathrm{~b}$ construct was difficult to purify and copurified with an E. coli protein, SlyD, from which it could not be separated (22). When expressed in genetically modified E. coli without the gene for SlyD (RY3041), the protein expresses poorly and is labile, requiring detergent and salt to stabilize, making it unsatisfactory for extensive biochemical characterization and analysis.

Consequently, we sought a more stable $\mathrm{C} 1 \mathrm{~b}$ model protein. We designed four constructs of varying length to empirically determine what region within $7 \mathrm{Clb}$ constitutes a functional folding domain. Of the four, one (aa 506-599) does not express and the other two (aa 483-584 and 506-596) copurify with SlyD. Only the construct, named $7 \mathrm{C} 1 \mathrm{~b}-\mathrm{S}$ (7C1b-Short), which has aa 506-584 of ACVII, expresses adequately when transformed into E. coli BL21(DE3) and can be purified to homogeneity without the contamination from SlyD (Figure 1A). Its molecular mass was verified using electrospray mass spectroscopy, which indicated a protein of $11228.7 \mathrm{Da}$ (expected $11223.5 \mathrm{Da}$ ). In gel filtration experiments $7 \mathrm{C} 1 \mathrm{~b}-\mathrm{S}$ elutes at approximately the expected molecular mass of $11.5 \mathrm{kDa}$ in the presence of a reducing agent, $1 \mathrm{mM}$ DTT (data not shown), suggesting that it exists in solution as a monomer in the presence of DTT.

Analysis of Fragments from Limited Proteolysis of $7 C 1 b$ $S$. Controlled proteolytic experiments were conducted to determine if $7 \mathrm{C} 1 \mathrm{~b}-\mathrm{S}$ is stably folded. A 10 -fold serial dilution of proteinase $\mathrm{K}$, a nonspecific protease, was applied first. If 7C1b-S were not stably folded, we would expect to see fairly uniform digestion. Instead, we observed a protected fragment of approximately $5 \mathrm{kDa}$ (Figure $1 \mathrm{~B}$ ). The fragments resulting from these digests were analyzed using Maldi-TOF mass spectroscopy. At the highest concentration $(1 \times)$, a $5042 \mathrm{Da}$ fragment was the only significant peak remaining, corresponding to the approximately $5 \mathrm{kDa}$ fragment observed with gel electrophoresis (Supporting Information, Figure S1). We isolated this fragment using HPLC and then performed $\mathrm{N}$-terminus sequencing to identify the first five residues. Sequencing results for each residue were as follows: (1) SGNDI, (2) RE, (3) TS, (4) ED, (5) DV. Of the possible combinations arising from these results, only one exists within the original $7 \mathrm{C} 1 \mathrm{~b}-\mathrm{S}$ protein prior to digestion, GRSED, which places this fragment in the C-terminus half of the protein (aa 538-582 in ACVII).

We then probed the protease-sensitivity of $7 \mathrm{C} 1 \mathrm{~b}-\mathrm{S}$ with three specific endoproteases, chymotrypsin, endoproteinase GluC, and endoproteinase ArgC. Knowing the specific cleavage site of each enzyme allows us to construct a map of protected versus vulnerable regions through mass spectroscopy analysis of fragments resulting from digests with each. The specificity for each enzyme are as follows: chymotrypsin, F, Y, W, M, and L, except before P; endoproteinase GluC, E, D, except before P; endoproteinase ArgC, 
A.

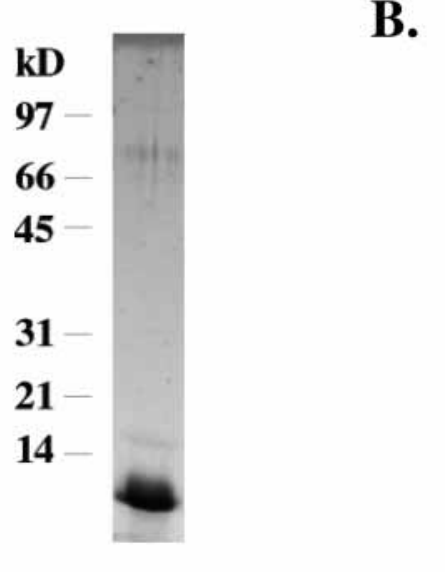

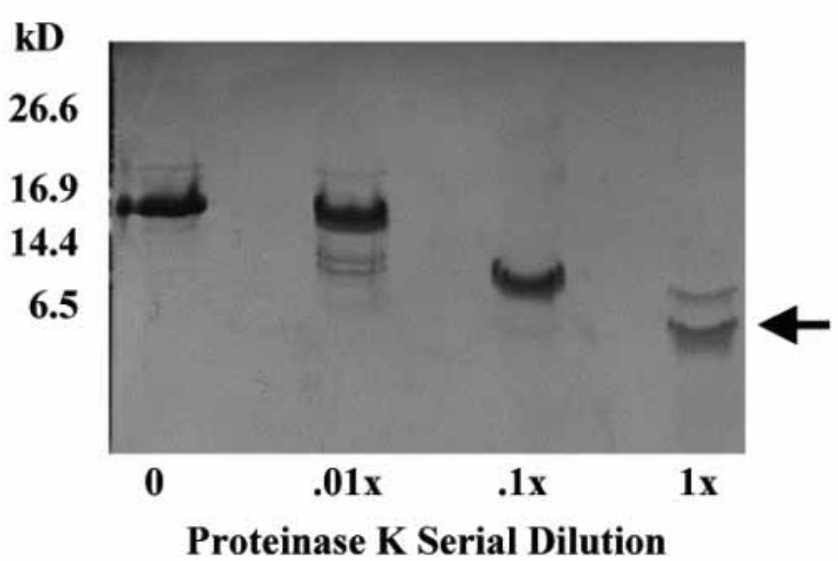

C.

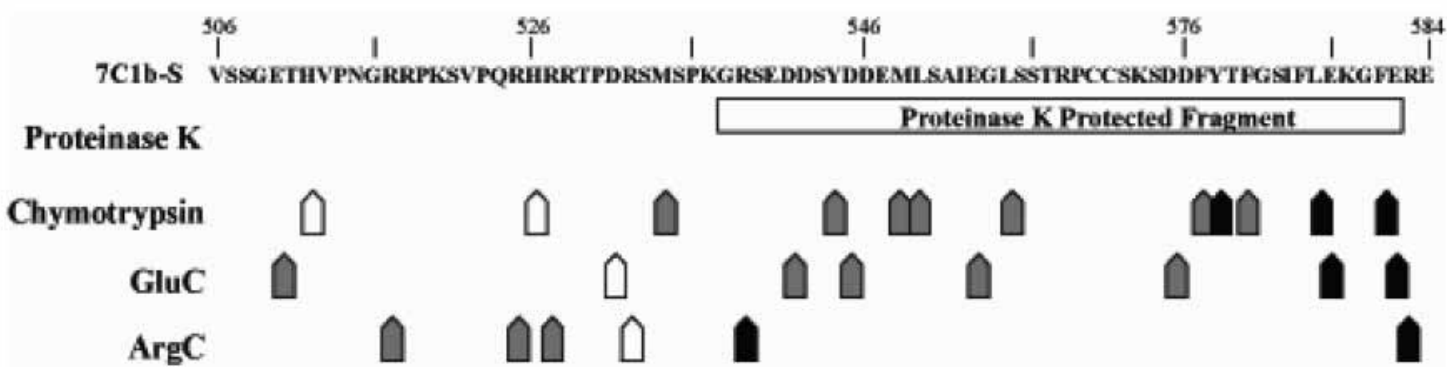

FIGURE 1: Characterization of 7C1b-S by limited proteolysis. (A) Coomassie stained SDS-PAGE gel showing 7C1b-S (1 $\mu \mathrm{g})$. (B) Coomassie stained $16.5 \%$ Tricine gel of serially diluted proteinase $\mathrm{K}$ digestion of $7 \mathrm{C} 1 \mathrm{~b}-\mathrm{S}$. $1 \times$ proteinase $\mathrm{k}(4 \mathrm{ng} / \mathrm{mL}) \mathrm{was}$ used to digest $0.34 \mathrm{mg} / \mathrm{mL}$ 7C1b-S for $30 \mathrm{~min}$. The arrow indicates the protected fragment. (C) Summary of the controlled proteolytic analysis of 7C1--S. Shown at top is the amino acid sequence of $7 \mathrm{C} 1 \mathrm{~b}-\mathrm{S}$. Below the sequence is a summary of results of analysis for each protease. For proteinase $\mathrm{K}$, the protected fragment identified in panels $\mathrm{A}$ and $\mathrm{B}$ is represented as an open bar. For chymotrypsin, endoproteinase GluC, endoproteinase $\mathrm{ArgC}$, arrowheads mark cleavage sites specific for that enzyme. Cleavage sites found to be protected are represented with white arrowheads, semiprotected with gray, and vulnerable sites with black.

$\mathrm{R}$, except before P. Results of these experiments are summarized in Figure 1C. We observe a consistently protected or semiprotected region in the N-terminus half of 7C1b-S, followed by a region of vulnerability approximately in the middle of the protein, followed by another semiprotected region at the $\mathrm{C}$-terminus half. The last $8-10$ residues appear to be vulnerable to some proteases. Our analysis suggests that $7 \mathrm{C} 1 \mathrm{~b}-\mathrm{S}$ exhibits a relatively stable, folded conformation, likely consisting of two primary folding regions, each constituting approximately half of the protein. Although these data suggest that $7 \mathrm{C} 1 \mathrm{~b}-\mathrm{S}$ is folded, they do not resolve the question of the conformational stability of the protein. Thus, we extended our characterization of 7C1b-S using biophysical analyses.

Secondary Structure Analysis of $7 C 1 b-S$ by Circular Dichroism and UV Raman Spectroscopy. Circular dichroism (CD) was used to further characterize the structural properties of $7 \mathrm{C} 1 \mathrm{~b}-\mathrm{S}$. Initial experiments with $\mathrm{CD}$ utilized a minimal buffer ( $5 \mathrm{mM}$ phosphate buffer, pH 7.2, and $100 \mathrm{mM} \mathrm{KCl}$ ) to reduce interference with the $\mathrm{CD}$ signal. Dilution of $7 \mathrm{C} 1 \mathrm{~b}-\mathrm{S}$ protein stock results in $42.5 \mu \mathrm{M}$ DTT in the final CD sample, referred to as the "low DTT" condition. Analysis of this spectrum for secondary structure estimates found little $\alpha$-helical content ( $\sim 5 \%)$, approximately $40 \% \beta$-strands, $22 \%$ turns, and $32 \%$ disordered. The spectra and secondary structure estimates within this low DTT condition are relatively stable. In testing the effects of temperature in fivedegree increments from 5 to $40{ }^{\circ} \mathrm{C}$, little change in estimated secondary structure was observed (Supporting Information, Figure S2). The effect of $\mathrm{pH} 8.0$ or no salt was tested in contrast to the original conditions of $\mathrm{pH} 7.2$ and $100 \mathrm{mM}$ $\mathrm{KCl}$. Again, little change was noted in the secondary structure (Supporting Information, Figure S3). Thus, the conformation observed in the low DTT condition is stable.

Conducting the experiments in a buffer more suitable to the protein $(10 \mathrm{mM}$ phosphate buffer, $\mathrm{pH} 7.2,50 \mathrm{mM} \mathrm{NaCl}$, and $1 \mathrm{mM}$ DTT) alters the CD spectrum of $7 \mathrm{C} 1 \mathrm{~b}-\mathrm{S}$ so that it more closely resembles the signature spectra typical for $\alpha$-helical structures. Figure 2A compares the CD spectra from the low DTT and the $1 \mathrm{mM}$ DTT conditions. The primary difference between these is a shift from putative $\beta$-strand structures $(40 \%)$ with low helical content $(\sim 6 \%)$ under low DTT conditions to greater helical content $(15-23 \%)$ with concomitant reduction in $\beta$-strand structures $(20-30 \%)$ in the presence of 20 -fold higher DTT concentration $(1 \mathrm{mM})$ (See Table S1 of the Supporting Information for secondary structure estimates for the entire concentration range). Estimates of turn regions and disordered regions remain approximately constant under both conditions.

A range of $7 \mathrm{C} 1 \mathrm{~b}-\mathrm{S}$ concentrations $(9-150 \mu \mathrm{M})$ was examined to determine whether $7 \mathrm{C} 1 \mathrm{~b}-\mathrm{S}$ conformation is concentration-dependent (Figure 2B). At higher concentrations, the $\mathrm{CD}$ spectra of $7 \mathrm{C} 1 \mathrm{~b}-\mathrm{S}$ resembled those found under low DTT conditions, with low helical content $(5-7 \%)$ and higher $\beta$-strand content (30-36\%). With decreasing concentration, we found a gradual shift toward the $1 \mathrm{mM}$ DTT- 


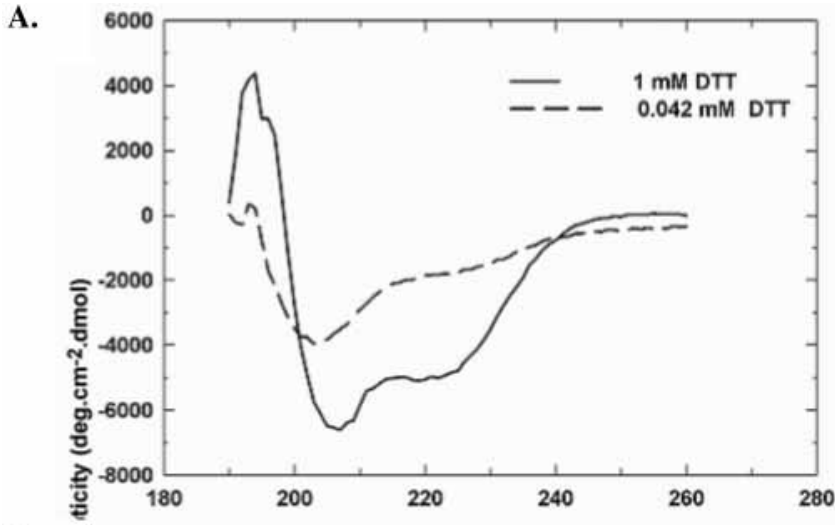

B.

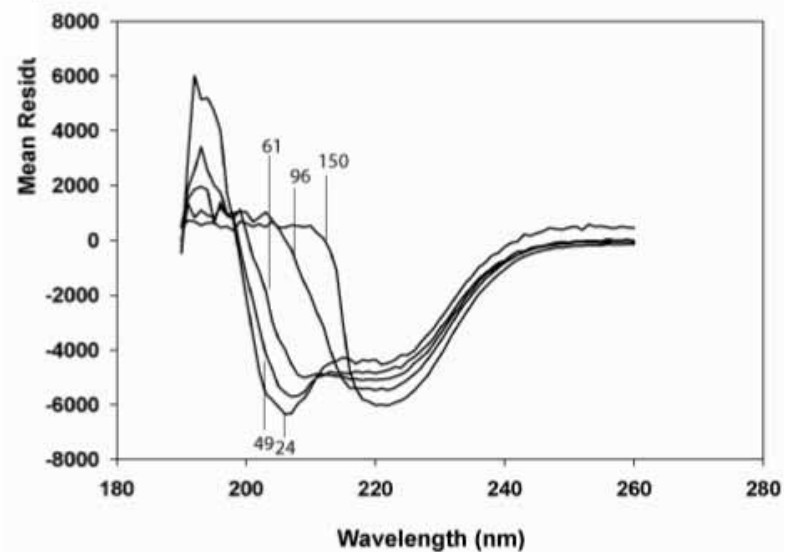

FIGURE 2: Circular dichroism (CD) spectra of 7C1b-S. (A) Comparison of CD spectra from 190 to $260 \lambda(\mathrm{nm})$ of $7 \mathrm{C} 1 \mathrm{~b}-\mathrm{S}$ in the presence of $1 \mathrm{mM}$ vs $42 \mu \mathrm{M}$ DTT $(31.5$ and $30 \mu \mathrm{M} 7 \mathrm{C} 1 \mathrm{~b}-\mathrm{S}$, respectively). Buffers: $10 \mathrm{mM}$ phosphate $\mathrm{pH} 7.2,50 \mathrm{mM} \mathrm{NaCl}$, and $1 \mathrm{mM}$ DTT; $5 \mathrm{mM}$ phosphate $\mathrm{pH} 7.2,100 \mathrm{mM} \mathrm{KCl}$, with 42 $\mu \mathrm{M}$ DTT residual from 7C1b-S stock preparation. Both experiments were conducted at $5{ }^{\circ} \mathrm{C}$. (B) Representative CD spectra from 190 to $260 \lambda(\mathrm{nm})$ of $24-150 \mu \mathrm{M}$ (as indicated) $7 \mathrm{C} 1 \mathrm{~b}-\mathrm{S}$ in buffer of $10 \mathrm{mM}$ phosphate $\mathrm{pH} 7.2,50 \mathrm{mM} \mathrm{NaCl}$, and $1 \mathrm{mM}$ DTT at $5{ }^{\circ} \mathrm{C}$.

like spectra with increasing helical content (up to $23 \%$ ) and decreasing $\beta$-strand content (down to $20 \%$ ), again with turn and disordered estimates remaining approximately constant.

UV Raman (UVRS) was used to corroborate the CD findings. UVRS measurements excited at $204 \mathrm{~nm}$ probe the vibrations of the amide backbone. Excitation at $204 \mathrm{~nm}$ occurs within the $\pi \rightarrow \pi^{*}$ electronic transitions of the peptide backbone. The vibrations that are resonance Raman enhanced are those involved in the $\pi \rightarrow \pi^{*}$ vibronic transitions. The typical vibrations enhanced include the amide I band around $1640 \mathrm{~cm}^{-1}$, which is mainly a carbonyl stretching vibration. Also enhanced are the amide (Am) II and III bands, around $\sim 1550 \mathrm{~cm}^{-1}$ and in the region $1200-1300 \mathrm{~cm}^{-1}$, which involve amide $\mathrm{C}-\mathrm{N}$ stretching and $\mathrm{N}-\mathrm{H}$ bending, and for extended conformations and disordered conformations, the $\mathrm{C} \alpha-\mathrm{H}$ symmetric bending vibration is enhanced. These bands show well-defined frequency and intensity dependencies on the local secondary structure $(28,32)$.

Figure 3a shows the concentration dependence of the 204 $\mathrm{nm}$ excited resonance Raman spectra of $7 \mathrm{C} 1 \mathrm{~b}-\mathrm{S}$. Spectra are dominated by the Am I band $\left(1665 \mathrm{~cm}^{-1}\right)$, the Am II band $\left(1557 \mathrm{~cm}^{-1}\right)$, and the Am III band $\left(1247 \mathrm{~cm}^{-1}\right)$. Additionally the protein spectra show a contribution at $\sim 1610 \mathrm{~cm}^{-1}$ from the aromatic ring breathing vibrations of Tyr and Trp residues (28). Comparing the spectra, we see very little spectral changes when going from higher to lower protein concentra-

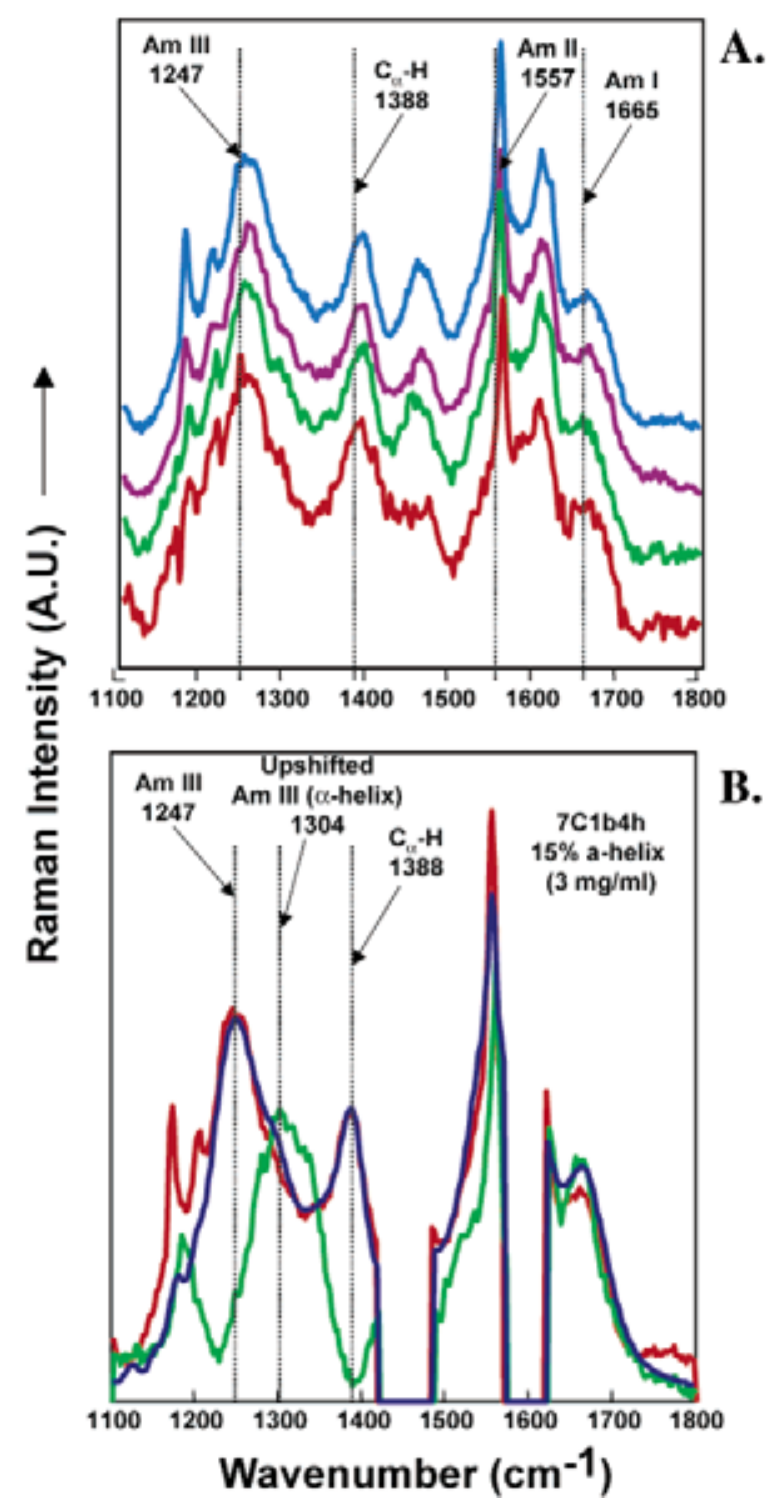

FiguRE 3: UV-resonance Raman spectra of 7C1b-S. (A) Concentration series of the UV resonance Raman spectra $(204 \mathrm{~nm}$ excitation) of 7C1b-S, at room temperature: $3 \mathrm{mg} / \mathrm{mL}$ (blue), 1.5 $\mathrm{mg} / \mathrm{mL}$ (violet), $0.6 \mathrm{mg} / \mathrm{mL}$ (green), and $0.4 \mathrm{mg} / \mathrm{mL}$ (red). The protein was dissolved in $50 \mathrm{mM}$ phosphate buffer at $\mathrm{pH} 7.3$ containing $1 \mathrm{mM}$ DTT and $50 \mathrm{mM} \mathrm{NaCl}$. The spectra of $7 \mathrm{C} 1 \mathrm{~b}-\mathrm{S}$ were obtained by subtracting spectra of the solution in the absence of protein from the ones containing $7 \mathrm{C} 1 \mathrm{~b}-\mathrm{S}$. (B) Calculated secondary structure Raman spectrum of $7 \mathrm{C} 1 \mathrm{~b}-\mathrm{S}$ (blue) vs the experimental one (red) obtained from $3 \mathrm{mg} / \mathrm{mL}$ protein aqueous solution, at $204 \mathrm{~nm}$ as excitation wavelength. The specific upshift of the Am III band and intensity decrease of the $\mathrm{C} \alpha-\mathrm{H}$ band in the Raman spectrum of a $\alpha$-helical protein (apomyoglobin) is shown for comparison (green). The regions around 1610 and $1450 \mathrm{~cm}^{-1}$ are excluded due to interference from aromatic amino acid ring vibrations and side-chain vibrations.

tions. The $\mathrm{C}_{\alpha} \mathrm{H}$ bending band $\left(1391 \mathrm{~cm}^{-1}\right)$, which is absent in $\alpha$-helical conformations (32), is also a dominant feature of our spectra. Both the shape and intensity of this band remain unchanged at different protein concentrations. Taken together, all these spectral features suggest low $\alpha$-helical secondary structure. We calculate a $7 \mathrm{C} 1 \mathrm{~b}-\mathrm{S}$ secondary structure of approximately $15 \% \alpha$-helical content, which does not change with concentration. For comparison, we also show in Figure $2 \mathrm{~b}$ the UV Raman spectrum of apomyoglobin, a protein that is $\sim 80 \% \alpha$-helical. 


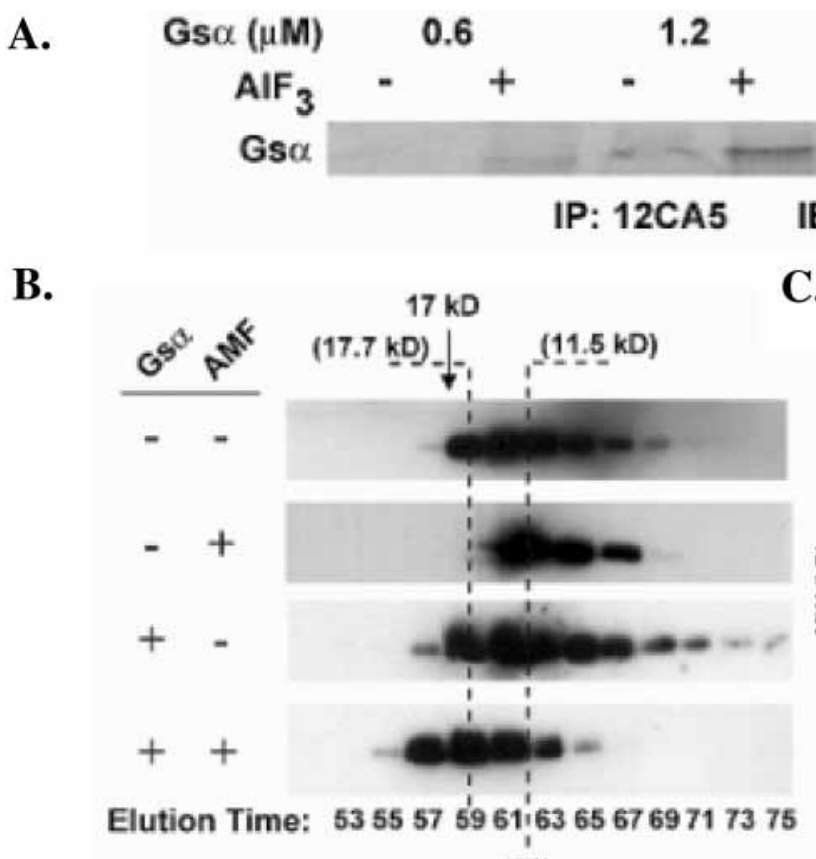

(62)
C.

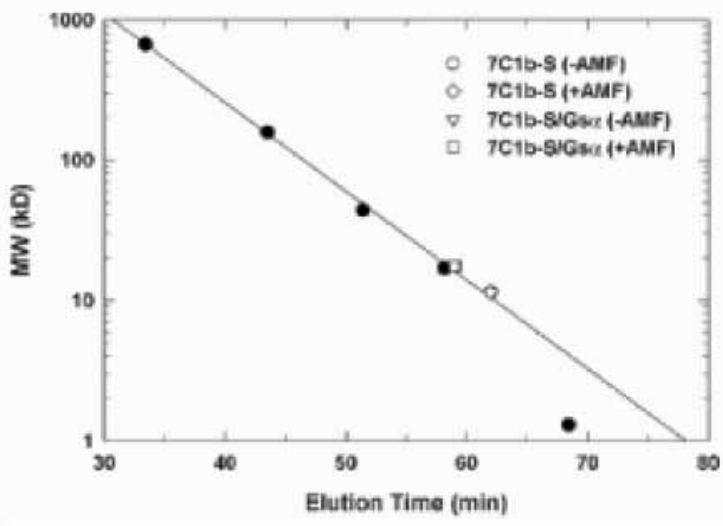

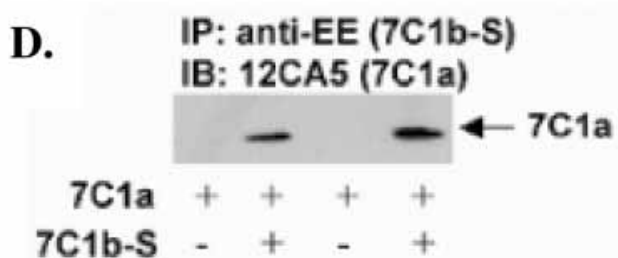

FIGURE 4: Interaction between $7 \mathrm{C} 1 \mathrm{~b}-\mathrm{S}$ and $\mathrm{Gs} \alpha$ and $7 \mathrm{C} 1 \mathrm{a}$. (A) $\mathrm{AlF}_{3}$ enhances binding of $7 \mathrm{C} 1 \mathrm{~b}(\Delta 2) / \mathrm{SlyD}$ with $\mathrm{Gs} \alpha$. $7 \mathrm{C} 1 \mathrm{~b}(\Delta 2) / \mathrm{SlyD}(6$ $\mu \mathrm{M}$ ) was mixed with the indicated concentration of $\mathrm{Gs} \alpha$ in the presence or absence of $30 \mu \mathrm{M} \mathrm{AlCl}_{3}, 10 \mathrm{mM} \mathrm{MgCl}$, and $10 \mathrm{mM} \mathrm{NaF}$ and immunoprecipitated with $12 \mathrm{CA} 5$ antibody (HA epitope tag of $7 \mathrm{C} 1 \mathrm{~b}(\Delta 2)$ ). Precipitates were analyzed with anti-Gs $\alpha$ antibody to detect Gs $\alpha$. (B) Immunoblot analysis (IB: anti-EE) of the migration of $400 \mu \mathrm{L}$ of $20 \mu \mathrm{M} 7 \mathrm{C} 1 \mathrm{~b}-\mathrm{S}$ through Superdex 200 gel filtration column alone and in the presence of $\mathrm{AMF}\left(50 \mu \mathrm{M} \mathrm{AlCl} 3,10 \mathrm{mM} \mathrm{Mg}{ }^{2+}\right.$, and $\left.10 \mathrm{mM} \mathrm{NaF}\right), 355 \mu \mathrm{M}$ Gs $\alpha$, and $355 \mu \mathrm{M}$ Gs $\alpha+\mathrm{AMF}$, as indicated. Elution buffer: $50 \mathrm{mM}$ Hepes $\mathrm{pH}$ 7.2, $100 \mathrm{mM} \mathrm{NaCl}, 1 \mathrm{mM}$ EDTA, $1 \mathrm{mM}$ DTT. Peak identification is indicated by dotted lines with estimated molecular mass labeled. Results representative of three experiments. (C) Plot of above results against standard curve. Elution peak (min)/estimated mass (kDa): 7C1b-S alone, 62/11.5; 7C1b-S + AMF, 62/11.5; 7C1b-S + Gs $\alpha, 62 / 11.5 ; 7 \mathrm{C} 1 \mathrm{~b}-\mathrm{S}+\mathrm{Gs} \alpha+\mathrm{AMF}$, 59/17.7. Standards: thyroglobulin $(670 \mathrm{kD})$, bovine $\gamma$-globulin $(158 \mathrm{kD})$, chicken ovalbumin $(44 \mathrm{kD})$, equine myoglobin $(17 \mathrm{kD})$, vitamin $\mathrm{B} 12(1.35 \mathrm{kD})$. (D) $7 \mathrm{C} 1 \mathrm{a}(0.7 \mu \mathrm{M})$ was incubated with and without $7 \mathrm{C} 1 \mathrm{~b}-\mathrm{S}(6 \mu \mathrm{M})$ and immunoprecipitated with anti-EE antibody (EE epitope tag of $7 \mathrm{C} 1 \mathrm{~b}-\mathrm{S})$. Precipitates were analyzed with $12 \mathrm{CA} 5$ antibody to detect the HA epitope tag of 7C1a. Wash conditions following immunoprecipitation: $1 \mathrm{M} \mathrm{NaCl}$ and either $0.75 \%$ (lanes 1 and 2) or $1 \% \mathrm{NP}-40$ (lanes 3 and 4 ).

Although the CD and UVRS data agree in terms of $\alpha$-helical content (i.e., for UVRS, approximately $15 \%$ and, for CD (with DTT), between 6 and 23\%, depending upon $7 \mathrm{C} 1 \mathrm{~b}-\mathrm{S}$ concentration with an average of $15 \%$ ), the two methods provide different estimates for the remainder of the protein. Both methods are known to be reliable for helical content but less so for other secondary structure; consequently, further structural determination will require rigorous structural analysis using NMR or CD.

$7 C 1 b-S$ Interacts with Gsa, $7 C 1 a$, and $7 C 2$. We hypothesize that $\mathrm{C} 1 \mathrm{~b}$ will interact with $7 \mathrm{C} 1 \mathrm{a}$ and/or $7 \mathrm{C} 2$ and possibly Gs $\alpha$. Gs $\alpha$ is a cardinal activator of all membranebound isoforms of mammalian adenylyl cyclase (4). In experiments using an earlier $\mathrm{Clb}$ construct in the presence of SlyD, $7 \mathrm{C} 1 \mathrm{~b} \Delta 2$, we found that $\mathrm{C} 1 \mathrm{~b}$ interacted with $\mathrm{Gs} \alpha$ in an activation-dependent manner (activated with AMF: 50 $\mu \mathrm{M} \mathrm{AlCl}_{3}, 10 \mathrm{mM} \mathrm{MgCl}$, and $10 \mathrm{mM} \mathrm{NaF}$ ) (Figure 4A). However, the presence of SlyD presumably bound to $7 \mathrm{C} 1 \mathrm{~b}$ confounds interpretation.

To test interaction between 7C1b-S and Gs $\alpha$, we used gel filtration. In the presence of Gs $\alpha$ activated with $\mathrm{AMF}$,
7C1b-S migrates as a larger molecule, eluting at an estimated molecular mass of $17.7 \mathrm{kDa}$. Alone or in the presence of Gs $\alpha$ not activated with AMF or with AMF only, 7C1b-S migrates as expected for its molecular mass of $11.2 \mathrm{kDa}$ (Figure 4B,C). This shift in elution is considerably less than what would be expected for the 7C1b-S/Gs $\alpha$ complex ( $~ 56$ $\mathrm{kD}$ ), suggesting a low affinity interaction between the two. This represents the first report showing the direct interaction between the $\mathrm{C} 1 \mathrm{~b}$ region and Gs $\alpha$.

We previously reported yeast two-hybrid experiments indicating an interaction between $7 \mathrm{C} 1 \mathrm{~b}$ and both $7 \mathrm{C} 1 \mathrm{a}$ and 7C2 (22). Consistent with our observation, an interaction between the $\mathrm{C} 2$ and $\mathrm{C} 1 \mathrm{~b}$ regions has been reported in type 5 adenylyl cyclase using yeast two-hybrid (17). We also used co-immunoprecipitation studies to demonstrate an interaction between $7 \mathrm{C} 1 \mathrm{~b} \Delta 2 / \mathrm{SlyD}$ and both $7 \mathrm{C} 1 \mathrm{a}$ and $7 \mathrm{C} 2$; however, this is confounded by the presence of SlyD (data not shown). To examine whether $7 \mathrm{C} 1 \mathrm{~b}-\mathrm{S}$ can directly interact with $7 \mathrm{Cla}$, we used co-immunoprecipitation. 7C1b-S is tagged with the EE epitope (33). 7C1a can be co-immunoprecipitated in the presence of $7 \mathrm{C} 1 \mathrm{~b}-\mathrm{S}$ using anti-EE monoclonal antibody, 
while no observable $7 \mathrm{C} 1 \mathrm{a}$ can be co-immunoprecipitated without 7C1b-S (Figure 4D), indicating an interaction between $7 \mathrm{Cla}$ and $7 \mathrm{C} 1 \mathrm{~b}-\mathrm{S}$.

7C1b-S Inhibits Gso-Activated Adenylyl Cyclase Activity of $7 \mathrm{Cla} / 7 \mathrm{C} 2$. There is evidence to suggest that $\mathrm{C} 1 \mathrm{~b}$ may play a role in the activation of adenylyl cyclase by Gs $\alpha$. Harry and colleagues (34) found that ACII and ACVI both exhibit a two-slope Gs $\alpha$ activation curve, suggestive of two binding sites, one high and one low affinity. They found that $\mathrm{C} 1 \mathrm{~b}$ plays a role in the second low affinity site and that phosphorylation of a serine near the $\mathrm{C}$-terminus of $\mathrm{C} 1 \mathrm{~b}$ can alter the Gs $\alpha$ response properties of ACVI (18). They speculate that $\mathrm{Clb}$ may contribute to a second Gs $\alpha$ binding site. Thus, we examined the effect of $7 \mathrm{C} 1 \mathrm{~b}-\mathrm{S}$ on the Gs $\alpha$ activation profile of $7 \mathrm{C} 1 \mathrm{a} / 7 \mathrm{C} 2$. We found that $7 \mathrm{C} 1 \mathrm{~b}-\mathrm{S}$ inhibits the adenylyl cyclase activity of $7 \mathrm{C} 1 \mathrm{a} / 7 \mathrm{C} 2$ by approximately $50-90 \%$, and such inhibition is noticeable only within a low Gs $\alpha$ concentration range, up to approximately $2 \mu \mathrm{M}$ (Figure $5 \mathrm{~A}$ ). At higher concentrations of Gs $\alpha, 7 \mathrm{C} 1 \mathrm{~b}-\mathrm{S}$ shows no effect. Notably, 7C1b-S shows no effect on basal or $\mathrm{Mn}^{2+}$-stimulated $7 \mathrm{C} 1 \mathrm{a} / 7 \mathrm{C} 2$ activities (Figure 5A and Supporting Information, Figure S4). The inhibition of Gs $\alpha$-activated activity of $7 \mathrm{C} 1 \mathrm{a} / 7 \mathrm{C} 2$ by $7 \mathrm{C} 1 \mathrm{~b}-\mathrm{S}$ is dose-dependent (Figure 5C). This suggests that $7 \mathrm{C} 1 \mathrm{~b}-\mathrm{S}$ modulates the activation of $7 \mathrm{C} 1 \mathrm{a} / 7 \mathrm{C} 2$ by modulating the binding of Gs $\alpha$ to the high-affinity Gs $\alpha$ binding site in 7C1a/ $7 \mathrm{C} 2$, not by altering the catalytic properties of enzyme.

Forskolin (Fsk) is a potent activator of most mammalian adenylyl cyclase isoforms. Alone, it exhibits little activation of $7 \mathrm{C} 1 \mathrm{a} / 7 \mathrm{C} 2$; however, in combination with $\mathrm{Gs} \alpha$, it potentiates activity 100 -fold or more (30). Fsk binds one of two pockets formed at the interface between $\mathrm{C} 1 \mathrm{a}$ and $\mathrm{C} 2$. The binding of $\mathrm{Fsk}$ to $\mathrm{C} 1 / \mathrm{C} 2$ promotes the proper alignment between $\mathrm{C} 1 \mathrm{a}$ and $\mathrm{C} 2$ to enhance catalytic activity (10). We tested whether 7C1b-S inhibition of Gs $\alpha$ activation is observed in the presence of Fsk $(100 \mu \mathrm{M}$; Figure 5B). Although $7 \mathrm{C} 1 \mathrm{~b}-\mathrm{S}$ has little effect on $7 \mathrm{C} 1 \mathrm{a} / 7 \mathrm{C} 2$ activity stimulated by Fsk alone (data not shown), when stimulated with Gs $\alpha$ and Fsk, 7C1b-S inhibits 7C1a/7C2 activity approximately $25-60 \%$ and is again only noticeable at lower concentrations (to $2 \mu \mathrm{M}$ ) of Gs $\alpha$ (Figure $5 \mathrm{C}$ ). From this we conclude that the observed inhibition from $7 \mathrm{C} 1 \mathrm{~b}-\mathrm{S}$ is present but diminished with Fsk potentiation.

Finally, activated membrane-bound type 7 adenylyl cyclase is sensitive to potentiation by $\mathrm{G} \beta \gamma$ (Supporting Information, Figure S5A); however, this has not been observed in any soluble model system, including our 7C1a/7C2 system (35). Like ACVII, ACII is potentiated by $\mathrm{G} \beta \gamma$ (19). In ACII, the $\mathrm{C} 1 \mathrm{~b}$ region has been shown to be essential for $\mathrm{G} \beta \gamma$ sensitivity (20). Consequently, we examined whether the addition of $7 \mathrm{C} 1 \mathrm{~b}-\mathrm{S}$ to $7 \mathrm{C} 1 \mathrm{a} / 7 \mathrm{C} 2$ would restore $\mathrm{G} \beta \gamma$ sensitivity to the soluble model system. Addition of $7 \mathrm{C} 1 \mathrm{~b}-\mathrm{S}$ to $7 \mathrm{C} 1 \mathrm{a} / 7 \mathrm{C} 2$ stimulated with $\mathrm{Gs} \alpha$ in the presence or absence of $\mathrm{G} \beta \gamma$ did not restore $\mathrm{G} \beta \gamma$ sensitivity (Supporting Information Figure $\mathrm{S} 5 \mathrm{~B})$. Although evidence suggests $\mathrm{C} 1 \mathrm{~b}$ is essential, it may not be sufficient to confer $\mathrm{G} \beta \gamma$ sensitivity.

\section{DISCUSSION}

Although the $\mathrm{C} 1 \mathrm{~b}$ region appears to play an important role in isoform specific regulation of adenylyl cyclase, it has been difficult to express and purify $\mathrm{Clb}$ as a functional domain.
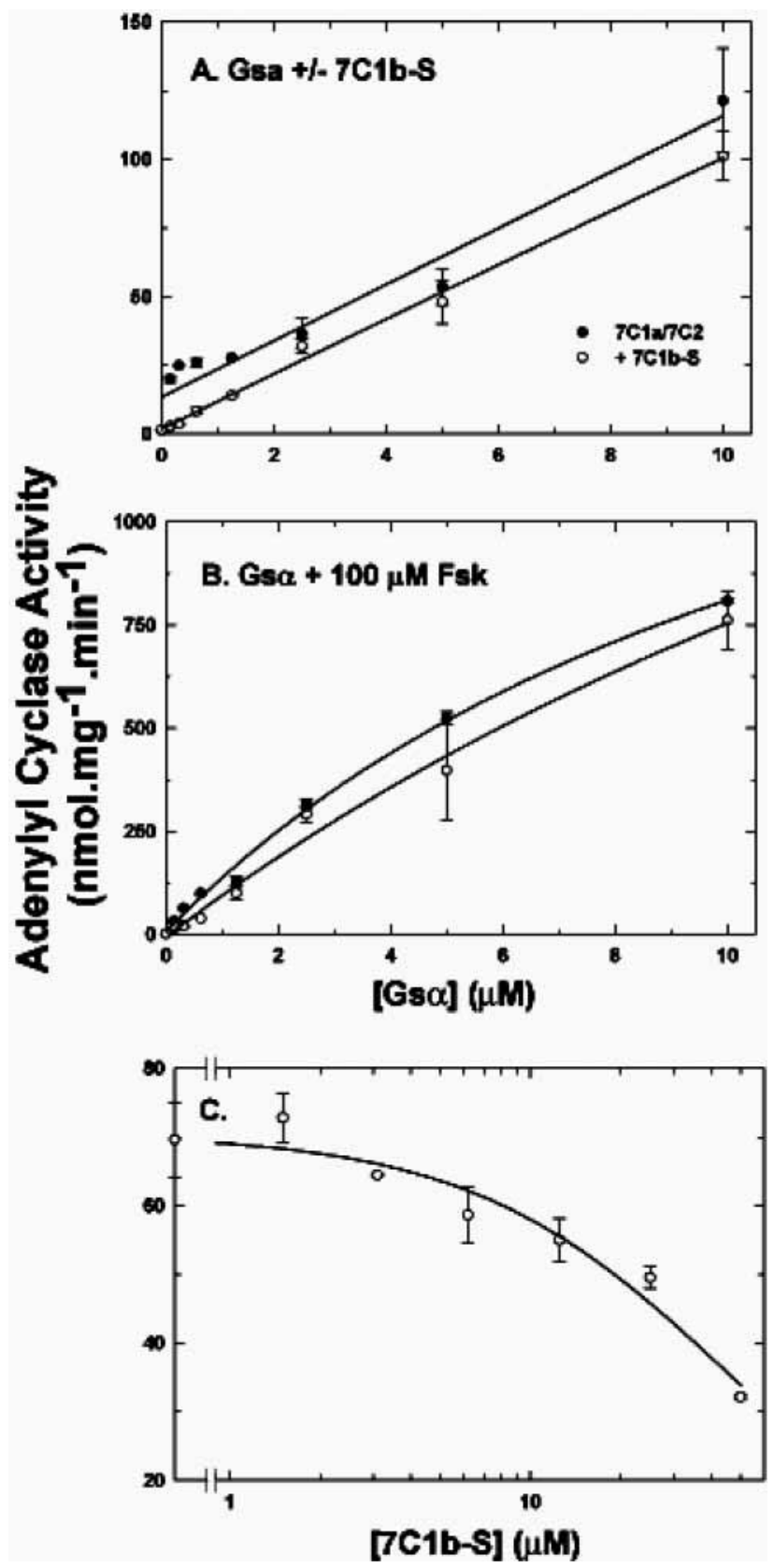

FIGURE 5: Effect of 7C1b-S on Gs $\alpha$ - and Gs $\alpha /$ Fsk-stimulated 7C1a/ 7C2 activity. (A) Gs $\alpha$ concentration-response curve $(0.0-10 \mu \mathrm{M})$ in the presence (open symbols) or absence (closed symbols) of $7 \mathrm{C} 1 \mathrm{~b}-\mathrm{S}(50 \mu \mathrm{M})$. (B) Gs $\alpha$ concentration-response curve $(0.0-10$ $\mu \mathrm{M})$ in the presence of $100 \mu \mathrm{M}$ forskolin and the presence or absence of $7 \mathrm{C} 1 \mathrm{~b}-\mathrm{S}(50 \mu \mathrm{M})$. (C) Effect of varying concentrations $(0.0-50 \mu \mathrm{M})$ of $7 \mathrm{C} 1 \mathrm{~b}-\mathrm{S}$ on Gs $\alpha$-stimulated $(2 \mu \mathrm{M}) 7 \mathrm{C} 1 \mathrm{a} / 7 \mathrm{C} 2$. All assays: $0.1 \mathrm{mg} / \mathrm{mL}$ BSA, $0.4 \mu \mathrm{M}$ each of 7C1a and 7C2, $20 \mathrm{~min}$ assay.

When expressed as an extension of $7 \mathrm{C} 1 \mathrm{a}$ or $5 \mathrm{C} 1 \mathrm{a}$, it is subject to proteolysis $(23,30,36)$. When expressed as a separate soluble protein, it expresses poorly, is subject to proteolysis, and is labile. We present here a model soluble $\mathrm{C} 1 \mathrm{~b}$ protein that represents a functional folding domain within this region. It expresses adequately, can be purified free of SlyD, is relatively stable, and in the presence of DTT exists in solution as a monomer.

Initial structural characterization suggests that $7 \mathrm{C} 1 \mathrm{~b}-\mathrm{S}$ is relatively stably folded, although it may be capable of adopting more than one stable conformation. We have found 
that this protein interacts with Gs $\alpha$ in an activation-dependent manner as well as with 7C1a and likely 7C2 (22). Although the affinity in all cases appears to be low, this is likely compensated by its proximity to $\mathrm{C} 1 \mathrm{a}$ and $\mathrm{C} 2$, as within the native enzyme $\mathrm{C} 1 \mathrm{~b}$ is in 1:1 stoichiometric ratio and in fixed proximity to the catalytic domains. Finally, 7C1b-S inhibits the Gs $\alpha$-activated adenylyl cyclase activity of $7 \mathrm{C} 1 \mathrm{a} / 7 \mathrm{C} 2$, likely through interaction with Gs $\alpha$. These properties suggest that $7 \mathrm{C} 1 \mathrm{~b}-\mathrm{S}$ may serve as a useful model of the $\mathrm{C} 1 \mathrm{~b}$ region in ACVII.

Although we show here that the $\mathrm{C} 1 \mathrm{~b}$ region inhibits the catalytic activity of $7 \mathrm{C} 1 \mathrm{a} / 7 \mathrm{C} 2$, within the native enzyme the regulatory properties conferred by this domain may be more complex. Inclusion of $\mathrm{C} 1 \mathrm{~b}$ in model systems (soluble or bisected membrane preparations) generally diminishes activity $(16,20,36)$. Consistent with an inhibitory role, $\mathrm{Ca}^{2+}$ bound to $\mathrm{C} 1 \mathrm{~b}$ in $\mathrm{ACV}$ and VI inhibits activity. In contrast, $\mathrm{Ca}^{2+}$-calmodulin bound to $\mathrm{C} 1 \mathrm{~b}$ in $\mathrm{ACI}$ activates the enzyme $(13,37) . \mathrm{G} \beta \gamma$ both inhibits (ACI) and potentiates (ACII, VII) adenylyl cyclase. In the case of ACII (and presumably closely related $\mathrm{ACVII}$ ), $\mathrm{C} 1 \mathrm{~b}$ has been shown to be essential for $\mathrm{G} \beta \gamma$ potentiation (20). In $\mathrm{ACI}, \mathrm{C} 1 \mathrm{~b}$ is not required for inhibition; however, in conjunction with the M2 region, it can confer $\mathrm{G} \beta \gamma$ inhibition (21). Finally, in the ACVIII-C splice variant in which a region of $\mathrm{C} 1 \mathrm{~b}$ is excised that corresponds exactly to $7 \mathrm{C} 1 \mathrm{~b}-\mathrm{S}$, the $K_{\mathrm{m}}$ of this variant is higher while it is more responsive to $\mathrm{Ca}^{2+}$-calmodulin (38). Thus, the nature of the regulatory properties of $\mathrm{C} 1 \mathrm{~b}$ within adenylyl cyclase appears to be complex, with the capacity to both diminish and enhance catalysis.

It is noteworthy that our $\mathrm{C} 1 \mathrm{~b}$ construct did not confer $\mathrm{G} \beta \gamma$ sensitivity to our soluble $7 \mathrm{C} 1 \mathrm{a} / 7 \mathrm{C} 2$ system. Although $\mathrm{C} 1 \mathrm{~b}$ has been shown to be critical in ACII G $\beta \gamma$ potentiation (20), it has not been shown to be sufficient. No soluble cyclase system to date has exhibited $\mathrm{G} \beta \gamma$ stimulation. Although it is possible that all soluble systems, including our $7 \mathrm{C} 1 \mathrm{~b}-\mathrm{S}$ protein, are simply lacking the critical residues in the $\mathrm{C} 1 \mathrm{~b}$ domain necessary for $\mathrm{G} \beta \gamma$ sensitivity, it is equally plausible that the M2 transmembrane domain may play a crucial role. As noted above, in ACI the $\mathrm{C} 1 \mathrm{~b}$ and M2 domains together can form a site conferring $\mathrm{G} \beta \gamma$ inhibition (21). Thus, we speculate that $\mathrm{C} 1 \mathrm{~b}$ and $\mathrm{M} 2$ together form a compound site for $\mathrm{G} \beta \gamma$ interaction. It is possible that $\mathrm{C} 1 \mathrm{~b}$ and $\mathrm{M} 2$ may also form a compound site for Gs $\alpha$ interaction and consequently our 7C1b-S construct may contain only a partial Gs $\alpha$ binding site (for a similar suggestion see 18). It may be that any soluble $\mathrm{C} 1 \mathrm{~b}$ protein needs to be studied in conjunction with a bisected membrane bound system, containing minimally $\mathrm{M} 2$, to elicit the full range of its functional potential, including both inhibitory and stimulatory properties.

The catalytic core of mammalian membrane-bound adenylyl cyclase is formed by the juxtaposition of the $\mathrm{C} 1 \mathrm{a}$ and $\mathrm{C} 2 \mathrm{a}$ domains of the enzyme, the catalytic cleft arising at their interface $(10,39) . \mathrm{C} 1 \mathrm{a}$ and $\mathrm{C} 2$ are tethered to the membrane by the transmembrane domains M1 and M2, respectively. We hypothesize that the $\mathrm{C} 1 \mathrm{~b}$ domain, linking $7 \mathrm{C} 1 \mathrm{a}$ to $7 \mathrm{C} 2$ by connecting $7 \mathrm{C} 1 \mathrm{a}$ to $\mathrm{M} 2$, is in an ideal position to alter the alignment between the two subunits and thereby regulate catalysis. The inhibition observed with $7 \mathrm{C} 1 \mathrm{~b}-\mathrm{S}$ suggests that C1b may serve as an internal constraint on catalysis, with enhancement of activity arising from relief of this constraint. Alternatively, if $\mathrm{C} 1 \mathrm{~b}$ acts through altering the alignment between the catalytic subunits, it may have the capacitythrough conformational changes - to both augment and diminish catalysis, serving as an internal gain control. Our $\mathrm{CD}$ data suggests that $\mathrm{C} 1 \mathrm{~b}$ may be able to adopt multiple conformations, possibly exhibiting a graded interconversion between $\alpha$-helices and $\beta$-strands. Unfortunately, the UVRS studies do not corroborate this. Thus, we can neither accept nor reject the $\mathrm{CD}$ data but will have to await more detailed structural information from NMR or X-ray crystallography. Nonetheless, that $\mathrm{C} 1 \mathrm{~b}$, in response to different ligands, adopts various conformations that alter the alignment of $\mathrm{C} 1 \mathrm{a}$ and $\mathrm{C} 2$ to regulate catalysis both positively and negatively is an intriguing possibility.

We believe understanding $\mathrm{C} 1 \mathrm{~b}$ function is critical for understanding isoform-specific adenylyl cyclase regulation. Moreover, if fully characterized, the $\mathrm{C} 1 \mathrm{~b}$ region may provide an ideal isoform-specific molecular target for development of pharmaceutical therapeutics involving adenylyl cyclase. Soluble model systems have been a powerful tool in addressing our understanding of adenylyl cyclase, and we believe this strategy can be extended to investigate the role of $\mathrm{C} 1 \mathrm{~b}$ in $\mathrm{AC}$ regulation and function. However, in our experience the $\mathrm{C} 1 \mathrm{~b}$ region is difficult to work with and constructing a soluble $\mathrm{C} 1 \mathrm{~b}$ protein is not trivial. We propose that $7 \mathrm{C} 1 \mathrm{~b}-\mathrm{S}$ can serve as a prototype for development of $\mathrm{C} 1 \mathrm{~b}$ models for other $\mathrm{AC}$ isoforms, allowing more comprehensive investigation of this domain.

\section{ACKNOWLEDGMENT}

We thank Mohammed Yousef for his assistance in circular dichroism studies, which were completed at the University of Chicago Biophysical Core Facility, Young-Sam Lee for his advice and assistance during the biophysical experiments, and Wei-Song He for her assistance in protein purification. We also thank Alexander Mikhonin for his assistance in spectral modeling.

\section{SUPPORTING INFORMATION AVAILABLE}

Figures showing Maldi-TOF spectroscopy of proteinase $\mathrm{K}$ digests of $7 \mathrm{C} 1 \mathrm{~b}-\mathrm{S}$, the effects of temperature, $\mathrm{pH}$, and salt on the circular dichroism spectra of $7 \mathrm{C} 1 \mathrm{~b}-\mathrm{S}$, a table summarizing the concentration effects on $7 \mathrm{C} 1 \mathrm{~b}-\mathrm{S}$ secondary structure as estimated by $\mathrm{CD}$, the effect of $7 \mathrm{C} 1 \mathrm{~b}-\mathrm{S}$ on $\mathrm{Mn}^{2+}$ stimulated activity, $\mathrm{G} \beta \gamma$ potentiation of membrane-bound adenylyl cyclase 7, and the effect of $\mathrm{G} \beta \gamma$ on soluble AC7 with and without $7 \mathrm{C} 1 \mathrm{~b}-\mathrm{S}$. This material is available free of charge via the Internet at http://pubs.acs.org.

\section{REFERENCES}

1. Linder, J. U., and Schultz, J. E. (2003) Cell Signal. 12, 10811089.

2. Taussig, R., and Gilman, A. G. (1995) Mammalian membranebound adenylyl cyclases. J. Biol. Chem. 270, 1-4.

3. Sunahara, R. K., Dessauer, C. W., and Gilman, A. G. (1996) Complexity and diversity of mammalian adenylyl cyclases, Annu. Rev. Pharmacol. Toxicol. 36, 461-480.

4. Smit, M. J., and Igengar, R. (1998) Mammalian Adenylyl Cyclases. Adv. Second Messenger Phosphoprotein Res. 32, 1-21.

5. Krupinski, J., and Cali, J. J. (1998) Molecular diversity of the adenylyl cyclases. Adv. Second Messenger Phosphoprotein Res. $32,53-79$.

6. Iyengar, R. (1993) Molecular and functional diversity of mammalian Gs-stimulated adenylyl cyclases. FASEB J. 7, 768-775. 
7. Hanoune, J., and Defer, N. (2001) Regulation and role of adenylyl cyclase isoforms. Annu. Rev. Pharmacol. Toxicol. 41, 145-174.

8. Krupinski, J., Coussen, F., Bakalyar, H. A., Tang, W. J., Feinstein, P. G., Orth, K., Slaughter, C., Reed, R. R., and Gilman, A. G. (1989) Adenylyl cyclase amino acid sequence: Possible channelor transporter-like structure. Science 244, 1558-1564.

9. Tang, W. J., Yan, S., and Drum, C. L. (1998) Class III adenylyl cyclases: Regulation and underlying mechanisms. Adv. Second Messenger Phosphoprotein Res. 32, 137-151.

10. Tesmer, J. J. G., Sunahara, R. K., Gilman, A. G., and Sprang, S. R. (1997) Crystal structure of the catalytic domains of adenylyl cyclase in a complex with Gs-alpha-GTP-gammaS. Science 278, 1907-1916.

11. Tang, W. J., and Hurley, J. H. (1998) Catalytic mechanism and regulation of mammalian adenylyl cyclases. Mol. Pharmacol. 54, 231-240.

12. Iyengar, R. (1993) Multiple families of Gs-regulated adenylyl cyclases. Adv. Second Messenger Phosphoprotein Res. 28, 2736.

13. Wu, Z., Wong, S. T., and Storms, D. R. (1993) Modification of the calcium and calmodulin sensitivity of the type I adenylyl cyclase by mutagenesis of its calmodulin binding domain. J. Biol. Chem. 268, 23766-23768.

14. Vorherr, T., Knopfel, L., Hofmann, F., Mollner, S., Pfeuffer, T., and Carafoli, E. (1993) The calmodulin binding domain of nitric oxide synthase and adenylyl cyclase. Biochemistry 32, 60816088.

15. Levin, L. R., and Reed, R. R. (1995) Identification of functional domains of adenylyl cyclase using in vitro chimeras. J. Biol. Chem. 270, 7573-7579.

16. Scholich, K., Barbier, A. J., Mullenix, J. B., and Patel, T. B. (1997) Characterization of soluble forms of nonchimeric type $\mathrm{V}$ adenylyl cyclases. Proc. Natl. Acad. Sci. U.S.A. 94, 2915-2920.

17. Scholich, K., Wittpoth, C., Barbier, A. J., Mullenix, J. B., and Patel, T. B. (1997) Identification of an intramolecular interaction between small regions in type $\mathrm{V}$ adenylyl cyclase that influences stimulation of enzyme activity by Gsalpha. Proc. Natl. Acad. Sci. U.S.A. 94, 9602-9607.

18. Chen, Y., Harry, A., Li, J., Smit, M. J., Bai, X., Magnusson, R., Pieroni, J. P., Weng, G., and Iyengar, R. (1997) Adenylyl cyclase 6 is selectively regulated by protein kinase A phosphorylation in a region involved in Gs-alpha stimulation. Proc. Natl. Acad. Sci. U.S.A. 94, 14100-14104.

19. Tang, W. J., and Gilman, A. G. (1991) Type-specific regulation of adenylyl cyclase by G protein beta gamma subunits. Science $254,1500-1503$.

20. Weitmann, S., Schultz, G., and Kleuss, C. (2001) Adenylyl cyclase type II domains involved in Gbetagamma stimulation. Biochemistry 40, 10853-10858.

21. Wittpoth, C., Scholich, K., Yigzaw, Y., Stringfield, T. M., and Patel, T. B. (1999) Regions on adenylyl cyclase that are necessary for inhibition of activity by beta gamma and G(ialpha) subunits of heterotrimeric G proteins. Proc. Natl. Acad. Sci. U.S.A. 96, 9551-9556.

22. Yan, S.-Z., Beeler, J. A., Chen, Y., Shelton, R., K., and Tang, W.-J. (2001) The regulation of type 7 adenylyl cyclase by its C1b region and Escherichia coli peptidylprolyl isomerase, SlyD. J. Biol. Chem. 276, 8500-8506.
23. Beeler, J. A., and Tang, W. J. (2003) Expression and purification of soluble adenylyl cyclase from Escherichia coli. Methods Mol. Biol. 237, 39-54.

24. Pace, C. N., Vajdos, F., Fee, L., Grimsley, G., and Gray, T. (1995) How to measure and predict the molar absorption coefgicient of a protein. Protein Sci. 4, 2411-2423.

25. Sreerama, N., and Woody, R. W. (2000) Estimation of protein secondary structure from circular dichroism spectra: Comparison of CONTIN, SELCON, and CDSSTR methods with an expanded reference set. Anal. Biochem. 287, 252-260.

26. Lednev, I. K., Karnoup, A. S., Sparrow, M. C., and Asher, S. A. (1999) alpha-Helix peptide folding and unfolding activation barriers: A nanosecond UV resonance Raman study. J. Am. Chem. Soc. 121, 8074-8086.

27. Chen, X. G., Lemmon, D. H., Brormett, R. W., and Asher, S. A. (1992) Convenient microsampling system for UV resonance Raman spectroscopy. Appl. Spectrosc. 47, 248-249.

28. Chi, Z., Chen, X. G., Holtz, J. S. W., and Asher, S. A. (1998) UV resonance Raman-selective amide vibrational enhancement: Quantitative methodology for determining protein secondary structure. Biochemistry 37, 2854-2864.

29. Yan, S.-Z., Hahn, D., Huang, Z.-H., and Tang, W.-J. (1996) Two cytoplasmic domains of mammalian adenylyl cyclase form a Gsalph- and forskolin-activated enzyme in vitro. J. Biol. Chem. 271, 10941-10945

30. Yan, S.-Z., and Tang, W.-J. (2002) Construction of soluble adenylyl cyclase from human form of mammalian adenylyl cyclase. Methods Enzymol. 345, 231-240.

31. Yan, S.-Z., and Tang, W.-J. (2002) Expression of $\alpha$ subunit of Gs in Escherichia coli. Methods Enzymol. 344, 171-175.

32. Asher, S. A., Ianoul, A., Mix, G., Boyden, M. N., Karnoup, A., Diem, M., and Schweitzer-Stenner, R. (2001) Dihedral angle dependence of the Amide III vibration: A uniquely sensitive UV resonance Raman secondary structural probe. J. Am. Chem. Soc. $123,11775-11781$.

33. Grussenmeyer, T., Scheidtmann, K., Hutchinson, M., Eckhart, W., and Walter, G. (1985) Complexes of polyoma virus medium T antigen and cellular proteins. Proc. Natl. Acad. Sci. U.S.A. 82, $7952-7954$.

34. Harry, A., Chen, Y., Magnusson, R., Iyengar, R., and Weng, G. (1997) Differential regulation of adenylyl cyclases by Galphas. J. Biol. Chem. 272, 19017-19021.

35. Yan, S., and Tang, W. J. (2001) Unpublished observations.

36. Sunahara, R. K., Dessauer, C. W., Whisnant, R. E., Kleuss, C., and Gilman, A. G. (1997) Interaction of Gs-alpha with the cytosolic domains of mammalian adenylyl cyclase. J. Biol. Chem. $272,22265-22272$.

37. Tang, W.-J., Krupinski, J., and Gilman, A. G. (1991) Expression and characterization of calmodulin-activated (type I) adenylylcyclase. J. Biol. Chem. 266, 8598-8603.

38. Cali, J. J., Parekh, R. S., and Krupinski, J. (1996) Splice variants of type VIII adenylyl cyclase: Differences in glycosylation and regulation by $\mathrm{Ca} 2+$ /calmodulin. J. Biol. Chem. 271, 1089-1095.

39. Zhang, G., Liu, Y., Ruoho, A. E., and Hurley, J. H. (1997) Structure of the adenylyl cyclase catalytic core. Nature 386 , 247-253.

BI049088+ 